e-Jurnal Ilmiah BIOSAINTROPIS (BIOSCIENCE-TROPIC)

Volume 6/ No.: 2 / Halaman 64 - 71 / Januari Tahun 2021

ISSN : 2460-9455 (e) - 2338-2805(p)

\title{
Efek Penambahan Bungkil Kedelai pada Pakan terhadap Pertambahan Berat Kelinci (Oryctolagus cuniculus)
}

\section{The Addition Effect of Soybean Meal in the Feed to the Rabbit (Oryctolagus cuniculus) Weight Gain}

\author{
Agus Dharmawan $^{1 *}$, Abdul Gofur ${ }^{1}$, Dania Merit Novitasari ${ }^{1}$ \\ ${ }^{1}$ Jurusan Biologi, Fakultas Matematika dan Ilmu Pengetahuan Alam Universitas Negeri Malang, Indonesia
}

\begin{abstract}
ABSTRAK
Pakan ternak didapatkan melalui pemanfaatan limbah sebagai komponen bahan pakan untuk memenuhi nutrisi yang dibutuhkan, salah satunya dengan memanfaatan bungkil kedelai sebagai bahan pakan. Penelitian bertujuan untuk mengetahui efek penambahan bungkil kedelai pada pakan terhadap pertambahan berat kelinci serta formula pakan yang efektif dan efisien. Penelitian eksperimental disusun secara Rancangan Acak Lengkap dengan empat perlakuan yaitu, kontrol (P0) berupa Susu Pap (SP), bungkil kedelai 8\% (P1), bungkil kedelai 10\% (P2) dan bungkil kedelai 12\% (P3) dengan empat ulangan. Data dianalisis menggunakan One Way Anova dengan Uji Lanjut Post Hoc. Hasil penelitian menunjukkan terdapat perbedaan pertambahan berat kelinci pada empat perlakuan penambahan bungkil kedelai pada pakan. Hasil analisis statistik pertambahan berat kelinci pada perlakuan kontrol (P0), bungkil kedelai 8\% (P1), dan bungkil kedelai 10\% (P2) tidak berbeda nyata. Perlakuan P3 menunjukkan pertambahan berat kelinci terendah. Perlakuan bungkil kedelai 10\% (P2) menunjukkan pertambahan berat kelinci tertinggi dengan nilai konversi pakan terendah. Sehingga perlakuan bungkil kedelai $10 \%$ (P2) merupakan formula pakan yang efektif dan efisien untuk menaikkan berat kelinci.
\end{abstract}

Kata kunci: Bungkil kedelai, kelinci, pertambahan berat kelinci

\begin{abstract}
Animal feed can be obtained through the use of waste as a component of feed ingredients to meet nutritional needs, which is by using soybean meal in feed ingredients. The study aims to determine the effect of adding soybean meal to feed on rabbit weight gain as well as the composition of feed which is effective and efficient. The experimental research was arranged in a Completely Randomized Design with four treatments namely, control (P0) in the form of Pap Milk (SP), 8\% soybean meal (P1), 10\% soybean meal (P2), and 12\% soybean meal (P3) with four replications. Data analysis using One Way Anova with Post Hoc Duncan Test. The results showed the differences in weight gain of rabbits in the four treatments of adding soybean meal to the feed. The result of statistical analysis of rabbit weight gain at the control treatment (P0), soybean meal $8 \%$ (P1), and soybean meal 10\% (P2) were not significantly different. The treatment of $12 \%$ soybean meal (P3) showed the lowest weight gain. The treatment of 10\% soybean meal (P2) showed the highest weight gain of rabbits with the lowest feed conversion value. So that the treatment of $10 \%$ soybean meal (P2) is an effective and efficient feed formula to increase the weight of rabbits.
\end{abstract}

Keywords: Soybean Meal, rabbit, rabbit weight gain

*) Dr. H. Agus Dharmawan, M.Si, Jurusan Biologi, FMIPA, Universitas Negeri Malang, Telp. 081331111139 dan email: agus.dharmawan.fmipa@um.ac.id

**) Prof. Dr. H. Abdul Gofur, M.Si. Jurusan Biologi, FMIPA, Universitas Negeri Malang, Telp. 081330390937 dan email: abdul.gofur.fmipa@um.ac.id

Diterima Tanggal 29 Desember 2020 - Dipublikasikan Tanggal 25 Januari 2021 
e-Jurnal Ilmiah BIOSAINTROPIS (BIOSCIENCE-TROPIC)

Volume 6/ No.: 2 / Halaman 64 - 71 / Januari Tahun 2021

ISSN : 2460-9455 (e) - 2338-2805(p)

\section{Pendahuluan}

Budidaya kelinci kegiatan usaha yang berpeluang untuk dikembangkan [1]. Ternak kelinci mempunyai beberapa keunggulan yaitu: 1) reproduksi tinggi dan perkembangbiakan cepat, 2) interval kelahiran pendek, dan 3) pemeliharaan tidak membutuhkan lahan yang luas [2]. Kelinci sebagai ternak alternatif penghasil daging dengan sumber protein hewani tinggi [3]. Struktur daging kelinci lebih halus dengan kandungan protein tinggi dibandingkan ternak lainnya sekitar 20,7\%, sedangkan daging domba $18,7 \%$ dan daging sapi 19,3\% dengan kadar lemak daging kelinci yang rendah [4]. Kelinci bermanfaat sebagai penghasil bulu, dan pupuk kandang [5].

Malang Raya (Kabupaten Malang, Kota Malang dan Batu) dikenal sebagai kota wisata yang semakin tahun semakin berkembang. Hal ini tentunya tidak hanya terbatas pada wisata alam dan wisata buatan saja, tetapi juga didukung oleh wisata kuliner. Salah satunya adalah wisata kuliner dengan bahan baku kelinci [6]. Adanya wisata kuliner ini, maka kegiatan budidaya kelinci semakin lama semakin marak di Malang Raya. Namun demikian, dalam budidaya kelinci terdapat beberapa kendala, salah satunya mengenai mahalnya harga pakan sehingga peternak mengalami kerugian produksi karena pakan sebagai penentu jumlah biaya produksi sekitar 60-80\% [7] dan berpengaruh terhadap produksi, pertumbuhan, serta kondisi ternak [8]. Oleh sebab itu diperlukan manajemen pakan yang mengutamakan kualitas dan kuantitas pakan melalui kombinasi bahan pakan untuk mencukupi nutrisi kelinci, sehingga didapatkan biaya pakan yang ekonomis [9].

Pakan yang baik bagi kelinci adalah pakan yang mengandung semua zat makan berupa protein, serat, lemak, vitamin, dan karbohidrat [10]. Protein sebagai nutrisi untuk pertumbuhan dan produksi bulu [11]. Karbohidrat sebagai sumber energi potensial untuk pemeliharaan tubuh \& jaringan tubuh [12]. Lemak sebagai sumber energi [5]. Serat kasar berfungsi dalam memudahkan proses pencernaan. Zat makan tersebut dapat diperoleh dari bahan lokal yang berpotensi apabila digunakan sebagai bahan campuran pakan ternak [13].

Bahan campuran pakan ternak bisa didapatkan melalui pemanfaatan limbah sebagai komponen bahan pakan untuk memenuhi kebutuhan nutrisi, salah satunya dengan memanfaatkan bungkil kedelai. Hal tersebut juga sebagai cara dalam mengurangi masalah peternak kelinci karena mahalnya harga pakan. Bungkil kedelai digunakan karena terjadi pembatasan penggunaan tepung ikan sebagai sumber protein [14]. Bungkil kedelai merupakan sisa proses pengolahan kedelai yang telah diambil minyaknya [15]. Bungkil kedelai merupakan bahan pakan dengan kandungan protein tinggi mencapai $51 \%$ dengan nilai kecernaan yang tinggi, bau yang sedap sehingga dapat meningkatkan palatabilitas [16]. Oleh sebab itu, sangat tepat jika bungkil kedelai sebagai sumber protein pada campuran pakan ternak.

Kelinci membutuhkan Digestible Energy (DE) 2500kkal $/ \mathrm{kg}$, karbohidrat 60\%, serat kasar 10$12 \%$, protein kasar $16 \%$ dan lemak $2 \%$ [6]. Kombinasi bahan pakan lokal seperti bungkil kedelai, dedak, pollard, ampas tebu dan tepung jagung berpotensi untuk mencukupi kebutuhan nutrisi ternak karena bungkil kedelai sumber protein mengandung protein kasar 51\%, karbohidrat 30\%, lemak kasar $5,7 \%$, serat kasar 5,9\% dan energi metabolisme $2330 \mathrm{kkal} / \mathrm{kg}$ [17]. Dedak padi sumber energi mengandung protein kasar 9,5\%, lemak kasar 13\%, serat kasar 11,4\%, kadar air 8\%-14\%, karbohidrat $66 \%$ dan energi termetabolis $2998 \mathrm{kcal} / \mathrm{kg}$ [18]. Pollard sumber energi mengandung serat kasar $8,1 \%$, protein kasar $16,9 \%$, karbohidrat $65 \%$, lemak kasar 5,1\%, dan energi metabolis $1140 \mathrm{kkal} / \mathrm{kg}$. Tepung jagung sumber energi mengandung protein kasar $16 \%$ dan serat kasar 2,1\%, lemak kasar 2,1\%, karbohidrat 73,7\% dan energi metabolisme $3300 \mathrm{kkal} / \mathrm{kg}$. Ampas tebu sumber serat mengandung serat kasar 36,75\%, lemak kasar 1,7\%, protein 4\%, dan karbohidrat 51,7\% [19].

Berdasarkan permasalahan penyediaan pakan pada budidaya kelinci yang ada di Malang Raya, maka penelitian ini dilakukan dengan tujuan untuk mengetahui efek penambahan bungkil kedelai pada pakan terhadap pertambahan berat kelinci dan formula pakan yang tepat, efektif serta efisien terhadap pertambahan berat kelinci (Oryctolagus cuniculus). 
e-Jurnal Ilmiah BIOSAINTROPIS (BIOSCIENCE-TROPIC)

Volume 6/ No.: 2 / Halaman 64 - 71 / Januari Tahun 2021

ISSN : 2460-9455 (e) - 2338-2805(p)

\section{Material dan Metode}

\section{Bahan dan Alat}

Bahan yang digunakan dalam penelitian ini adalah air, kertas label, bungkil kedelai, pollard, ampas tebu, dedak, tepung jagung dan kelinci lokal berjenis kelamin jantan sejumlah 16 ekor, umur 5 minggu, berat $510 \pm 65$ g/ekor dari Peternak Kelinci Mandiri Desa Ngijo Karangploso Malang. Alat yang digunakan dalam penelitian ini berupa mesin perajang, alat penepung, alat pencetak pelet, nampan plastik, pengaduk, tempeh, timbangan digital, plastik mika, rak susun besi, talang karet, kandang ukuran 60x30x40cm, tempat minum, tempat makan, sikat pembersih kandang, dan sapu lidi.

\section{Metode}

Penelitian eksperimental yang dilakukan dengan perlakuan penambahan beberapa konsentrasi bungkil kedelai yaitu $8 \%, 10 \%$ dan 12\% serta penggunaan pakan pasaran berupa Susu Pap (SP) sebagai kontrol. Rancangan percobaan yang digunakan yaitu Rancangan Acak Lengkap (RAL) dengan 4 perlakuan dan 4 ulangan. Penghitungan pakan dilakukan dengan Metode Trial \& Error, ditunjukkan pada Tabel 1.

Tabel 1. Penghitungan Pakan P1, P2 dan P3 (Bungkil Kedelai 8\%, 10\% dan 12\%)

\begin{tabular}{|c|c|c|c|c|c|c|}
\hline Perlakuan & Bahan & Protein & Karbohidrat & $\begin{array}{c}\text { Prosentase } \\
\text { Perlakuan } \\
(\%)\end{array}$ & $\begin{array}{c}\text { Total } \\
\text { Protein }\end{array}$ & $\begin{array}{c}\text { Total } \\
\text { Karbohidrat }\end{array}$ \\
\hline \multirow{5}{*}{$\begin{array}{l}\text { P1 (Bungkil } \\
\text { Kedelai 8\%) }\end{array}$} & Bungkil kedelai & 51 & 30 & 8 & 408 & 240 \\
\hline & Pollard & 16,9 & 65 & 30 & 507 & 1950 \\
\hline & Jagung & 16 & 73,7 & 32 & 512 & 2358,4 \\
\hline & Dedak & 9,5 & 66 & 15 & 142,5 & 990 \\
\hline & Ampas tebu & 4 & 51,7 & 15 & 60 & 775,5 \\
\hline \multicolumn{4}{|c|}{ TOTAL } & 100 & $16,3 \%$ & $63,139 \%$ \\
\hline \multirow{5}{*}{$\begin{array}{c}\mathrm{P} 2 \\
\text { (Bungkil } \\
\text { Kedelai } \\
10 \% \text { ) }\end{array}$} & Bungkil kedelai & 51 & 30 & 10 & 510 & 300 \\
\hline & Pollard & 16,9 & 65 & 25 & 422,5 & 1625 \\
\hline & Jagung & 16 & 73,7 & 30 & 480 & 2211 \\
\hline & Dedak & 9,5 & 66 & 17 & 161,5 & 1122 \\
\hline & Ampas tebu & 4 & 51,7 & 18 & 72 & 930,6 \\
\hline \multicolumn{4}{|c|}{ TOTAL } & 100 & $16,4 \%$ & $61,886 \%$ \\
\hline \multirow{5}{*}{$\begin{array}{c}\text { P3 } \\
\text { (Bungkil } \\
\text { Kedelai } \\
12 \% \text { ) }\end{array}$} & Bungkil kedelai & 51 & 30 & 12 & 612 & 360 \\
\hline & Pollard & 16,9 & 65 & 13 & 219,7 & 845 \\
\hline & Jagung & 16 & 73,7 & 30 & 480 & 2211 \\
\hline & Dedak & 9,5 & 66 & 27 & 256,5 & 1782 \\
\hline & Ampas tebu & 4 & 51,7 & 18 & 72 & 930,6 \\
\hline \multicolumn{4}{|c|}{ TOTAL } & 100 & $16,4 \%$ & $61,286 \%$ \\
\hline
\end{tabular}

\section{Cara Kerja}

Tahapan penelitian meliputi 6 tahapan yaitu: 1) Tahap persiapan pakan meliputi pembelian bahan pakan serta pencetakan pellet. 2) Tahap persiapan tempat pemeliharaan meliputi penyiapan rak susun dan kandang. 3) Tahap persiapan hewan uji dengan pembelian hewan uji berupa kelinci dari 
e-Jurnal Ilmiah BIOSAINTROPIS (BIOSCIENCE-TROPIC)

Volume 6/ No.: 2 / Halaman 64 - 71 / Januari Tahun 2021

ISSN : 2460-9455 (e) - 2338-2805(p)

Asosisasi Peternak Mandiri Desa Ngijo Karangploso Kabupaten Malang. 4) Tahap perlakuan pakan dengan pemberian pakan dan minum pada pagi pukul 08.00 WIB dan sore pukul 16.00 WIB. Sisa pakan dikumpulkan dan ditimbang pada keesokan harinya. 5) Tahap pemeliharaan hewan uji meliputi pembersihan kandang dan pemeriksaan keadaan hewan uji. 6) Tahap pengambilan data dilakukan dengan penimbangan berat kelinci setiap satu minggu sekali. Data dianalisis menggunakan Uji Komparasi Analisis of Variance (Anova) dengan Uji Lanjut Post Hoc Duncan untuk mengetahui perbedaan efek perlakuan pakan terhadap pertambahan berat kelinci.

\section{Hasil dan Diskusi}

\section{Hasil Penelitian}

Berdasarkan hasil penimbangan berat kelinci yang dilakukan setiap satu minggu sekali selama 5 minggu penelitian, didapatkan nilai pertambahan berat kelinci yang disajikan pada Gambar 1.

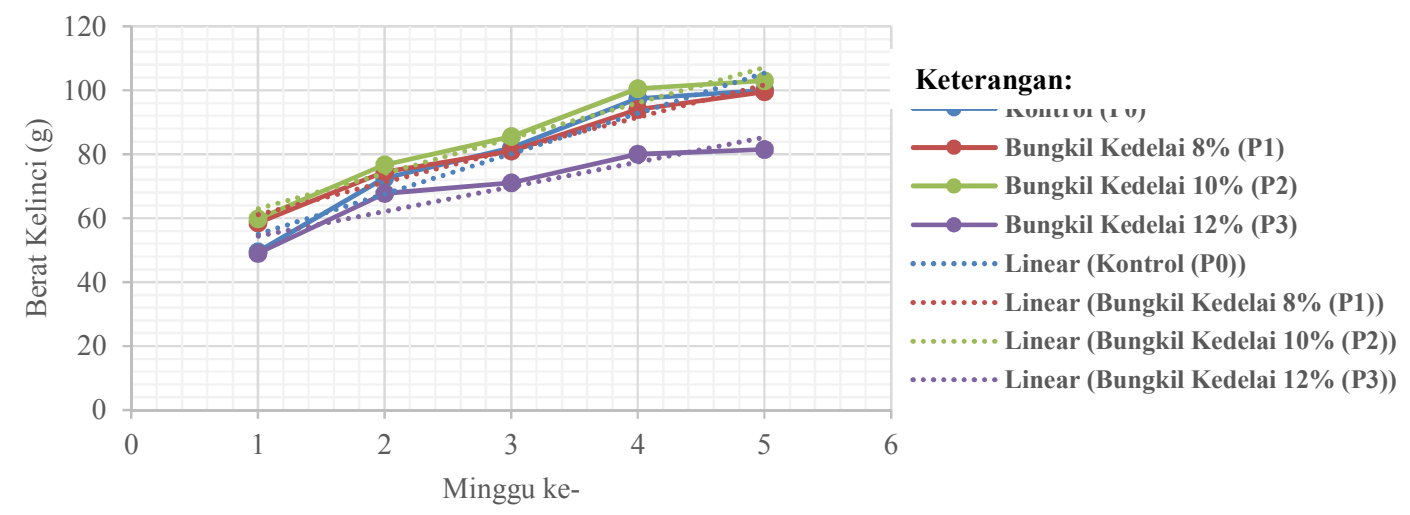

Gambar 1. Pertambahan Berat Kelinci/minggu (g/ekor/minggu)

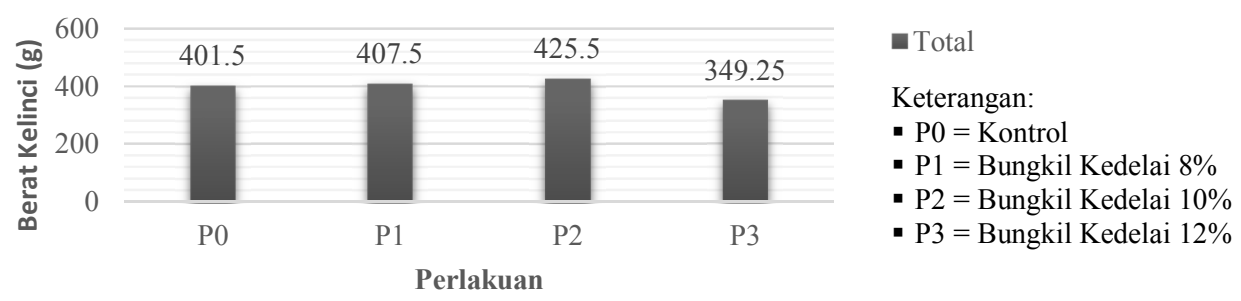

Gambar 2. Diagram Pertambahan Berat Kelinci (g/ekor)

Berdasarkan Gambar 1, seluruh perlakuan menunjukkan grafik yang meningkat, masingmasing perlakuan mengalami penambahan berat pada setiap minggu. Minggu pertama dan kedua penelitian belum menunjukkan hasil yang berbeda antar perlakuan, sedangkan pertambahan berat kelinci mulai menunjukkan nilai yang berbeda antar perlakuan di minggu ketiga penelitian. Apabila dilihat dari nilai total pertambahan berat kelinci disajikan pada Gambar 2.

Pada Gambar 2, pertambahan berat kelinci tertinggi pada perlakuan P2 sebesar 425,5 g/ekor, sedangkan terendah pada perlakuan P3 sebesar 349,25 g/ekor. Perlakuan pemberian konsentrasi 
e-Jurnal Ilmiah BIOSAINTROPIS (BIOSCIENCE-TROPIC)

Volume 6/ No.: 2 / Halaman 64 - 71 / Januari Tahun 2021

ISSN : 2460-9455 (e) - 2338-2805(p)

bungkil kedelai yang berbeda pada pakan dalam penelitian pada setiap kelompok memberikan efek yang berbeda nyata dengan nilai signifikansi $0,002(\mathrm{P}<0,05)$. Untuk mengetahui perbedaan perlakuan pakan terhadap nilai rerata pertambahan berat kelinci dilakukan Uji Lanjut Post Hoc Duncan yang disajikan pada Tabel 2 .

Tabel 2. Analisis Statistik Uji Lanjut Duncan Nilai Pertambahan Berat Kelinci

\begin{tabular}{|c|c|c|c|c|c|}
\hline \multirow[b]{2}{*}{ Perlakuan } & & \multirow[b]{2}{*}{$\mathrm{N}$} & \multicolumn{2}{|c|}{ Subset for alpha $=0.05$} & \multirow{2}{*}{ Notasi } \\
\hline & & & 1 & 2 & \\
\hline $\begin{array}{l}\text { Konsentrasi } \\
\text { (P3) }\end{array}$ & $12 \%$ & 4 & 349.2500 & & $\mathrm{a}$ \\
\hline Kontrol (P0) & & 4 & & 401.5000 & $\mathrm{~b}$ \\
\hline Konsentrasi $\&$ & (P1) & 4 & & 407.5000 & $\mathrm{~b}$ \\
\hline $\begin{array}{l}\text { Konsentrasi } \\
\text { (P2) }\end{array}$ & $10 \%$ & 4 & & 425.5000 & $\mathrm{~b}$ \\
\hline
\end{tabular}

Berdasarkan notasi pada Uji Lanjut Duncan yang disajikan pada Tabel 2 menunjukkan bahwa perlakuan kontrol, pemberian konsentrasi bungkil kedelai $8 \%$ dan pemberian konsentrasi bungkil kedelai $10 \%$ menunjukkan hasil yang tidak berbeda nyata $(\mathrm{P} \geq 0,05)$, sedangkan perlakuan konsentrasi bungkil kedelai $12 \%$ menunjukkan hasil yang berbeda nyata dengan perlakuan lainnya. Berdasarkan hasil penimbangan sisa pakan yang dilakukan setiap hari pada masing-masing perlakuan, didapatkan nilai konversi pakan (Ratio Feed Conversion) yang disajikan pada Tabel 3.

Tabel 3. Konversi Pakan Kelinci selama Penelitian

\begin{tabular}{cccc}
\hline Perlakuan & $\begin{array}{c}\text { Total Pakan } \\
\text { (gram) }\end{array}$ & $\begin{array}{c}\text { Total Kenaikan } \\
\text { Berat } \\
\text { (gram) }\end{array}$ & Konversi \\
\hline Kontrol (P0) & 1398,3 & 401,5 & 3,5 \\
Bungkil Kedelai 8\% (P1) & 1452,2 & 407,5 & 3,6 \\
Bungkil Kedelai 10\% (P2) & 1430,2 & 425,5 & 3,4 \\
Bungkil Kedelai 12\% (P3) & 1340,5 & 349,3 & 3,8 \\
\hline
\end{tabular}

Berdasarkan Tabel 3, dapat diketahui nilai konversi pakan hasil penelitian relatif sama antar perlakuan. Nilai konversi terendah pada perlakuan pemberian konsentrasi bungkil kedelai $10 \%$ sebesar 3,4 dan tertinggi pada perlakuan pemberian konsentrasi bungkil kedelai $12 \%$ sebesar 3,8.

\section{Pembahasan}

Penambahan bungkil kedelai yang berbeda pada pakan di minggu pertama dan kedua penelitian belum menunjukkan hasil yang berbeda sehingga pakan pada masing-masing perlakuan tidak memberikan efek negative pada pertambahan berat kelinci dibuktikan dengan nilai pertambahan berat kelinci yang relatif sama. Nilai pertambahan berat kelinci mulai menunjukkan hasil yang berbeda pada minggu ketiga perlakuan, dimana penambahan bungkil kedelai $12 \%$ (P3) memberikan nilai pertambahan berat kelinci terendah pada setiap minggu perlakuan.

Perlakuan pemberian bungkil kedelai $12 \%$ (P3) menunjukkan nilai pertambahan berat terendah karena terjadi ketidakseimbangan komposisi pakan pada perlakuan P3 sehingga mempengaruhi unsur nutrisi pada pakan. Perlakuan pakan P3 mengandung bahan pakan sumber serat berupa dedak padi dengan prosentase paling tinggi daripada perlakuan lainnya yaitu sebesar $27 \%$. Menurut Tim Laboratorium Ilmu dan Teknologi Pakan IPB [20], batas maksimum pemberian dedak 
e-Jurnal Ilmiah BIOSAINTROPIS (BIOSCIENCE-TROPIC)

Volume 6/ No.: 2 / Halaman 64 - 71 / Januari Tahun 2021

ISSN : 2460-9455 (e) - 2338-2805(p)

padi pada pakan adalah sekitar 25\%, sedangkan komposisi perlakuan pakan P3 tersusun atas dedak padi dengan konsentrasi $27 \%$ yang mana melebihi batas maksimum pemberian dedak padi pada pakan, sehingga mempengaruhi kualitas pakan tersebut.

Tingginya prosentase dedak padi pada pakan menyebabkan pakan memiliki sifat voluminous, oleh sebab itu tingginya prosentase dedak padi pada perlakuan P3 menyebabkan pakan tersebut kurang palatabel bagi kelinci [5]. Kelinci tidak menyukai pakan yang memiliki sifat voluminous karena lebih cepat memenuhi lambung [21], hal inilah yang menjadi pembatas dalam konsumsi pakan [22].

Dedak padi merupakan bahan pakan dengan kandungan serat yang tinggi sebesar 16\% [18]. Pakan dengan serat kasar tinggi mengakibatkan jalannya makanan lebih lambat sehingga ruang dalam saluran pencernaan cepat penuh [23]. Hal ini mengakibatkan ternak menjadi cepat kenyang, karena kelinci tidak dapat mencerna serat secara baik, ketika kandungan serat kasar meningkat menyebabkan penyerapan zat makanan yang lain berkurang [8], dengan begitu akan menyebabkan penurunan pertambahan berat kelinci [24].

Nilai pertambahan berat kelinci relatif sama antara perlakuan kontrol (P0), penambahan bungkil kedelai $8 \%(\mathrm{P} 1)$ dan penambahan bungkil kedelai $10 \%(\mathrm{P} 2)$ karena formula pakan pada ketiga perlakuan memiliki nutrient yang hampir sama dan tingkat kesukaan atau palatabilitasnya sama. Konsumsi nutrien yang hampir sama dalam pakan menghasilkan nilai pertambahan berat yang tidak berbeda nyata pula [25]. Ternak yang mengkonsumsi ransum dengan kandungan zat makanan cenderung sama memperlihatkan pertambahan berat yang hampir sama [26]. Akan tetapi, perlakuan penambahan bungkil kedelai 10\% (P2) pada pakan menunjukkan nilai pertambahan berat kelinci yang lebih unggul yaitu sebesar 425,5 g/ekor, sehingga perlakuan tersebut dapat digunakan sebagai pakan alternatif pada ternak kelinci.

Nilai konversi pakan hasil penelitian relatif sama antar perlakuan karena kandungan nutrien dalam masing-masing perlakuan hampir sama, sehingga ketersediaan nutrien untuk diserap tubuh juga sama [27]. Oleh sebab itu pertumbuhan kelinci dari masing-masing perlakuan juga hampir sama. Perbedaan angka konversi pakan dipengaruhi oleh konsumsi bahan kering, pertambahan berat kelinci dan konsumsi pakan [28]. Apabila nilai pertambahan berat kelinci relatif sama maka akan didapatkan nilai konversi pakan yang relatif sama pula [29].

Konversi pakan hasil penelitian terendah pada perlakuan pemberian konsentrasi bungkil kedelai 10\% (P2) sebesar 3,4, sedangkan tertinggi pada perlakuan pemberian konsentrasi bungkil kedelai 12\% (P3) sebesar 3,8. Hal ini sejalan dengan hasil dari penelitian terdahulu bahwa rerata nilai konversi pakan kelinci adalah 3,57 [5]. Hal ini menunjukkan bahwa semua hewan uji dapat merespon pakan dengan baik dibuktikan dengan nilai konversi pakan berkisar antara 2,8-4,0 [30].

\section{Kesimpulan}

Berdasarkan penelitian dapat disimpulkan bahwa pemberian substitusi bungkil kedelai yang maksimal ke dalam pakan dan formula pakan yang efisien untuk pertambahan berat kelinci adalah perlakuan penambahan bungkil kedelai dengan konsentrasi $10 \%$ (P2) karena menunjukkan pertambahan berat kelinci tertinggi dengan konversi pakan sebesar 3,4 sehingga merupakan formula pakan yang efektif untuk meningkatkan pertambahan berat kelinci sebesar 425,5 g/ekor.

\section{Ucapan Terima Kasih}

Ucapan terima kasih yang sebesar-besarnya kami sampaikan kepada Rektor Universitas Negeri Malang, Indonesia yang telah memberikan dukungan dana untuk penelitian ini melalui PNBP No.3.3.16 / UN32 / KP / 2020. 
e-Jurnal Ilmiah BIOSAINTROPIS (BIOSCIENCE-TROPIC)

Volume 6/ No.: 2 / Halaman 64 - 71 / Januari Tahun 2021

ISSN : 2460-9455 (e) - 2338-2805(p)

\section{Daftar Pustaka}

[1] Wibowo, B., Sumanto dan Rafif. 2008. Pemanfaatan dan Analisis Ekonomi Usaha Ternak Kelinci di Pedesaan. Lokakarya Nasional Potensi dan Peluang Pengembangan Usaha Kelinci. Balai Penelitian Ternak. Bogor. Hal. 139-143.

[2] Damron. W. S. 2017. Introduction to Animal Science. 6th Edition. Prentice Hall International. New Jersey. 704 pp.

[3] Muslih, D., I. Pasek., P. Wayan., Rossuartini and Bram, B.2005. Tatalaksana Pemberian Pakan untuk Menunjang Agribisnis Ternak Kelinci. Pusat Penelitian dan Pengembangan Peternakan Bogor. Hal. 61.

[4] Rukmana, R. 2005. Budidaya Rumput Unggul Hijauan Makanan Ternak. Edisi I. Penerbit Kanisius. Yogyakarta. Hal. 71.

[5] Nuriyasa, I.M., Mastika, I.M., Puger, A.W., Puspani, E. dan Wirawan, I.W. 2013. Performans Kelinci Lokal (Lepus nigricollis) yang Diberi Ransum dengan Kandungan Energi Berbeda. Majalah Ilmiah Peternakan. 16(1), hal.12-17. doi: 10.24843/MIP.2013.v16.i01.p03. URL: https://ojs.unud.ac.id/index.php/mip/article/view/9211.

[6] Marhaeniyanto, E. dan Susanti, S. 2017. Penggunaan Konsentrat Hijau untuk Meningkatkan Produksi Ternak Kelinci New Zealand White. Jurnal Ilmu-Ilmu Peternakan. 27(1), hal. 28-39. doi: 10.21776/ub.jiip.2017.027.01.04.

[7] Cheeke, P.R. 2005. Applied Animal Nutrition: Feed and Feeding. 3th Edition. Pearson and Prentice Hall. New Jersey. 604 pp.

[8] Sarwono, B. 2007. Kelinci Potong dan Hias. Edisi IX. Agromedia Pustaka. Jakarta. Hal. 146.

[9] Qisthon, A. 2012. Pengaruh Imbangan Hijauan - Konsentrat dan Waktu Pemberian Ransum terhadap Produktivitas Kelinci Lokal Jantan. Jurnal Penelitian Pertanian Terapan. 12(2), hal.69-74. URL: https://jurnal.polinela.ac.id/index.php/JPPT/article/view/200.

[10] Mudjiman, A. 2011. Makanan Ikan. Edisi Revisi. Jakarta: Penebar Swadaya. Hal. 190.

[11] Mc Donald, P., Edward, R.A., Greenhalgh, J.F.D., Morgan, C.A., Sinclair, L.A and Wilkinson, R.G. 2010. Animal Nutrition. 7th Edition. Prentice Hall. New Jersey. 692 pp.

[12] Ali, Usman. dan Badriyah. 2011. Intensifikasi Pemeliharaan Kelinci Penghasil Daging Menggunakan Limbah Industri Tempe dan Onggok Terfermentasi dalam Pakan Komplit. Jurnal Agriekstensia. 1(1), hal. 25-34. URL: https://sinta.ristekbrin.go.id/affiliations/detail?q=Intensifikasi+Pemeliharaan+Kelinci+Pen ghasil+Daging+Menggunakan+Limbah+Industri+Tempe+dan+Onggok + Terfermentasi + da lam+Pakan+Komplit\&search $=1 \& \mathrm{id}=2056 \&$ view $=$ documents.

[13] Thomas, A., Gandara, F.D.L., Gomez, A.G., Perez, L., and Jover, M. 2005. Utilization of Soybean Meal as an Alternative Protein Source in the Mediterranean Yellowtail, Seriola Dumerili. J Aquaculture Nutrition. 11(5), hal. 333-340. Retrieved June, $03^{\text {th }}, 2020$. doi: 10.1111/j.1365-2095.2005.00365.x.

[14] Rasyaf, M. 2008. Panduan Beternak Ayam Pedaging. Edisi IV. Penebar Swadaya. Jakarta. Hal. 179.

[15] Mathius, I W. dan Sinurat, A. P. 2001. Pemanfaatan Bahan Pakan Konvensional untuk Ternak. Balai Penelitian Ternak Bogor. 11(2), hal. 20-31. Tanggal Akses 2 Juni 2020. URL: http://medpub.litbang.pertanian.go.id/index.php/wartazoa/article/download/754/763.

[16] Pramono, A., Kustono., D. T. Widayati., P. P. Putro., E. Handayanta. Dan Hartadi, H. 2013. Evaluasi Proteksi Sabun Kalsium sebagai Pakan Suplemen Berdasarkan Kecernaan Bahan Kering, Bahan Organik dan pH In Vitro di dalam Rumen dan Pasca Rumen. Jurnal Sains Peternakan. 11(2), hal.70-78. doi: 10.20961/sainspet.v11i2.4828. 
e-Jurnal Ilmiah BIOSAINTROPIS (BIOSCIENCE-TROPIC)

Volume 6/ No.: 2 / Halaman 64 - 71 / Januari Tahun 2021

ISSN : 2460-9455 (e) - 2338-2805(p)

[17] Wahyuni, I. M. D., Muktiani, A., dan Christianto , M. 2014. Penentuan Dosis Tanin dan Saponin untuk Defaunasi dan Peningkatan Fermentabilitas Pakan. Jurnal Ilmu dan Teknologi Peternakan. 3(3), hal. 133-140. URL: http://journal.unhas.ac.id/index.php/peternakan/article/view/788.

[18] Zuprizal. 2000. Komposisi Kimia Dedak Padi sebagai Bahan Pakan Lokal dalam Ransum Ternak. Edisi Tambahan. Buletin Peternakan. Hal. 282-286.

[19] Tewari, M., Singh, V.K., Gope, P.C., and Chaudhary, A.K. 2012. Evaluation of Mechanical Properties of Bagasse-Glass Fiber Reinforced Composite. J Mater Environ Sciences. 3(1), hal. $\quad 187-194 . \quad$ Retrieved June, 03 ${ }^{\text {th }}$ 2020. URL: https://www.jmaterenvironsci.com/Document/vol3/17-JMES-153-2011-Tiwari.pdf.

[20] Tim Laboratorium Ilmu dan Teknologi Pakan IPB. 2012. Pengetahuan Bahan Makanan Ternak. CV Nutri Sejahtera. Bogor. Hal. 75.

[21] Sarwono, B. 2005. Beternak Kelinci Unggul. Penebar Swadaya. Jakarta. Hal. 100.

[22] Garsetiasih, R., Heriyanto, N. M. dan Atmaja, J. 2003. Pemanfaatan Dedak Padi sebagai Pakan Tambahan Rusa. Puslitbang Hutan dan Konservasi Alam. Bogor. Buletin Plasma Nutfah. 9(2), hal. 23-27. Tanggal Akses 05 Juni 2020. URL: http://ejurnal.litbang.pertanian.go.id/index.php/bpn/article/view/6066/0.

[23] Agunsoye, J.O., dan Aigbodion, V.S. 2013. Bagasse Filled Recycled Polyethylene BioComposites: Morphological And Mechanical Properties Study. J Results And Physic. 3(1), hal. 187-194. Retrieved June, 03 ${ }^{\text {th }}$, 2020. URL: https://doi.org/10.1016/j.rinp.2013.09.003.

[24] Cunningham, M., Latour, M.A. and Acker, D. 2004. Animal Science and Industry. VII Edition. Pearson Prentice Hall. New Jersey. 760 pp.

[25] Mucra, D. A. 2005. Pengaruh Pemakaian Pod Kakao sebagai Pengganti Jagung dalam Ransum terhadap Pertambahan Bobot Badan dan Efisiensi Penggunaan Ransum. Jurnal Peternakan. 2(2), hal. 37-44. doi: http://dx.doi.org/10.24014/jupet.v2i2.214.

[26] Fathi, A.N., Iskandar, S. dan Hamdan. 2014. Kecernaan Kulit Daging Buah Kopi dengan Fermentasi Mol dalam Ransum Pelet Pakan Kelinci Peranakan Rex. Jurnal Peternakan $\begin{array}{llll}\text { Integratif. } & 3(3), & \text { hal. } & \text { U19-328. }\end{array}$ https://jurnal.usu.ac.id/index.php/jpi/article/viewFile/12596/5478.

[27] Brahmantiyo, B., Raharjo, S., Mansjoer. dan Martojo. 2010. Performa Produksi Kelinci di Kabupaten Magelang, Jawa Tengah. Seminar Nasional Teknologi Peternakan dan Veteriner. Bogor. Hal. 582-587. Tanggal Akses 05 Juni 2020. URL: https://repository.ipb.ac.id/jspui/bitstream/123456789/83493/1/82.\%20Performa\%20Produ ksi\%20Kelinci\%20Di\%20Kabupaten\%20Magelang\%20Jawa\%20Tengah.pdf.

[28] Basuki, P. 2002. Dasar Ilmu Ternak Potong dan Kerja. Pengantar Ilmu Ternak Potong dan Kerja Laboratorium Fakultas Peternakan. Universitas Gadjah Mada Press. Yogyakarta.

[29] Chelry, S., Mas'ud., Y.R.L. Tulung., J. Umboh. dan Rahasia, C.A. 2015. Pengaruh Pemberian Beberapa Jenis Hijauan terhadap Performans Ternak Kelinci. Jurnal Zootek. 35(2), hal. 289-294. doi:10.35792/zot.35.2.2015.8494.

[30] Maryani., D. Kardaya. dan Dihansih, E. 2015. Performa Produksi Kelinci Lokal yang Diberikan Pakan Tambahan Tepung Daun Sirsak (Annona Muricata L) dan Zeolit. Jurnal Peternakan Nusantara. 1(1), hal. 17-24. doi: 10.30997/jpnu.vli1.149.

[31] Sugiyono, N., Elindratiningrum dan Primandini, Y. 2015. Determinasi Energi Metabolis Dan Kandungan Nutrisi Hasil Samping Pasar Sebagai Potensi Bahan Pakan Lokal Ternak Unggas. Jurnal Agripet, 15(1), hal. 41-45. doi: https://doi.org/10.17969/agripet.v15i1.2298. 